Egyptian Journal of Rabbit Science, 30(2): 125- 145 (2020)

\title{
EFFECT OF USING BAGASSE AS A SOURCE OF NATURAL FIBER INGREDIENT AND ADSORBENT MATERIAL FOR AFLATOXIN IN GROWING RABBITS RATIONS ON GROWTH PERFORMANCE
}

\author{
H. A. Abo-Eid' ; M. S. Abousekken'; Amal A. Abou Hagar ${ }^{2}$ and T. S. \\ Abdel-ghany ${ }^{2}$ \\ ${ }^{1}$ Sustainable development of Environment and its Project Management \\ Department, Environmental Studies and Research Institute, University of \\ Sadat City, Menofiya, Egypt. \\ 2 Regional Center for Foods and feeds, Agricultural Research Center, \\ Ministry of Agriculture. Egypt.
}

Corresponding author: H. A. Abo-Eid; Email: hosni.aboeid@esri.usc.edu.eg hosny_abo_eid@yahoo.com

\begin{abstract}
This study was carried out to determine the effect of feeding dietary bagasse as a source of natural fiber ingredient and adsorbent for aflatoxins (AFs) in growing rabbits diets and to evaluate using dietary bagasse on growth performance, digestibility coefficients of nutrients, nutritive value, some blood constituents and economical efficiency of New Zealand White rabbits (NZW). The study involved fifty four NZW growing rabbits of aged 5 weeks with initial body weight mean of $751.8 \pm 35.62 \mathrm{~g}$. Animals were divided into nine equal groups and fed treatment diets for 8 weeks. The experimental groups were: control or basal diet $\left(T_{1}\right)$, basal diet supplemented with low dose of AFs

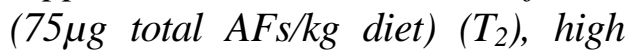

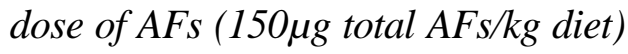
$\left(T_{3}\right), 3 \%$ of bagasse $\left(T_{4}\right), 6 \%$ of bagasse $\left(T_{5}\right), 3 \%$ of bagasse with low dose of aflatoxin $\left(T_{6}\right), 6 \%$ of bagasse with low dose of aflatoxin ( $\left.T_{7}\right), 3 \%$ of
\end{abstract}

bagasse with high dose of aflatoxin $\left(T_{8}\right)$ and $6 \%$ of bagasse with high dose of aflatoxin $\left(T_{9}\right)$. Results of live body weight at 13 week of age of both $T_{7}$ and $T_{9}$ groups recorded numerical higher body weight value compared to control group $\left(T_{1}\right), T_{2}$ and $T_{3}$ groups. $T_{3}$ group recorded significantly $(P<0.05)$ the highest daily feed consumption during periods; 5-9 and 5-13 weeks compared to control group $\left(T_{1}\right)$ and other groups. The best significant $(P<0.05)$ value of the feed conversion ratio was recorded with $T_{6}$ group at 9-13 weeks of age and the whole experiment period compared to $T_{2}$ group. While $T_{9}$ group recorded the best significant $(P<0.05)$ value of the feed conversion ratio compared to $T_{3}$ group. Also, $T_{4}$ and $T_{5}$ groups achieved the significant $(P<0.05)$ better value of feed conversion compared to control group $\left(T_{1}\right)$. The values of DM, OM, CP, EE and NFE for $T_{5}$ group were higher compared to 
control $\left(T_{1}\right)$ and $T_{4}$ group. Generally, $T_{6}$ group recorded significantly $(P<0.05)$ higher values of nutrient digestibility, DCP and TDN compared to $T_{2}$ group. While, $T_{9}$ group recorded significantly $(P<0.05)$ higher values of digestibility nutrients, DCP and TDN compared to $T_{3}$ group. Blood constituents results showed that changes in serum total protein (TP), and albumin (ALb) of rabbits treated with two doses low and high aflatoxins $\left(T_{2}\right.$ and $\left.T_{3}\right)$ caused a significant decrease in both values when compared with control group $\left(T_{1}\right)$. Supplementation of 3\% or $6 \%$ bagasse with low or high doses of aflatoxins ( $T_{6}$ to $T_{9}$ ) showed a significant increase in both parameters when compared to groups treated with aflatoxins singly $\left(T_{2}\right.$ and $\left.T_{3}\right) . T_{6}$ and $T_{9}$ groups showed $a$ significant decrease in both parameters when compared to $T_{2}$ and $T_{3}$ groups. The results showed the lowest value of serum creatinine and urea obtained with $T_{7}$ group. $T_{7}$ and $T_{9}$ groups showed a significant decrease in serum ALT, AST, ALP activity and cholesterol comparing with $T_{2}$ and $T_{3}$ groups. The results showed that the highest value of total PI recorded for $T_{6}$ group followed by $T_{5}$ group.

Conclusively, based on the results obtained in this study, it was established that using $6 \%$ of bagasse in the rations of growing rabbit's achieved improvements in growth performance parameters. At the same time, presence of bagasse alleviated the detrimental effect of aflatoxin.

Keywords: Bagasse, Aflatoxin, performance, economic efficiency.

\section{INTRODUCTION}

In Egypt, there is a broad gap between animal needs and the available fodder. Also, the fast increase in the cost of sources of animal protein is now an urgent need to increase the size of livestock. It has been observed that rabbits production is one of the best sources to mitigate the low consumption of animal protein prevalent in developing countries because of specific characteristics of rabbits meat (Maidala and Istifanus, 2012). Contamination of mycotoxins in feed is a global problem. Among mycotoxins, aflatoxins are one of the most dangerous toxins found in animal feeds (Williams et al., 2004). One of the recent methods of detoxifying products contaminated with mycotoxins is to use non-nutrient adsorbents in the diet to reduce the mycotoxins absorption from the gastrointestinal tract. Several workers reported that the adsorbent in the feed could selectively bind mycotoxins during digestion and pass without harm from the gastrointestinal tract of the animals. The main advantages of adsorbents are the safety, low cost and ease of adding them to animal feed (Avantaggiato et al., 2005 and Khadem et al., 2012). Due to the increasing number of information about aflatoxin contamination in feeds, there is a high demand for 
practical, simple and cost-effective detoxification methods. (Zahoor and Khan, 2018).

Bagasse is the fibrous residue of a sugarcane stalk after crushing and extracting the juice (Almeida et al., 2018). Bagasse is the main by-product of the sugarcane industry. It is one of the largest agricultural wastes in the world. Around 54 million tons of dry bagasse are produced annually worldwide and large amounts of it are burned in the fields, which creates a serious pollution problem. Hence, using this agricultural waste as an adsorbent material that had low cost could avoid the accumulation that leads to environmental problems (De Gisi et al., 2016 and Siqueira et al., 2020). One of the advantages of bagasse is that it is available during any time of fodder shortage and is less expensive compared to other traditional roughage sources. Thus, bagasse is the only viable alternative, in the short and medium-term, as roughage for animal feed (Barros et al., 2010 and Almeida et al., 2018).

Therefore, the objective of this research was to determine the effect of feeding dietary bagasse as a source of natural fiber ingredient and adsorbent for aflatoxins in growing rabbits diets and to evaluate using dietary bagasse on growth performance, digestibility coefficients of nutrients, nutritive value, some blood plasma constituents and economical efficiency of growing New Zealand White (NZW) rabbits.

\section{MATERIALS AND METHODS}

The present study was carried out at Farm of Sustainable Development Department, Environmental Studies and Research Institute, University of Sadat City, Menufiya Governorate, Egypt during January to March, 2017. The laboratory work was done at Regional Center for Food and Feeds, Agriculture Research Center. Aspergillus flavus NRRL (3145) was obtained from the National Research Center (Dokki, Giza). Aflatoxins (B1, $B_{2}, G_{1}$ and $G_{2}$ ) were obtained from Sigma Chemical Company (St Louis, MO, USA). Bagasse was obtained from local juice stores in Cairo, Egypt.

\section{Preparation of aflatoxins dose for rabbit experiment}

The solution containing AFs consisted of a mixture of aflatoxin $\mathrm{B}_{1}$, $\mathrm{B}_{2}, \mathrm{G}_{1}$ and $\mathrm{G}_{2}$ at a total concentration of $7.5 \mu \mathrm{g}$ AFs/ $\mathrm{ml}$ as a ratio of 8: 2: 4: 1, respectively used to prepare 2 final concentrations of AFs, $1 \mu \mathrm{g}$ AFs and $2 \mu \mathrm{g}$ AFs (St. Louis, Mo USA). 


\section{Preparation of dietary bagasse}

Bagasse was obtained from local juice stores. Oven drying was done in a cabinet oven with air circulation at $60 \mathrm{C}^{\circ}$ overnight whereas dried bagasse was milled by laboratory mill to pass a $2.0 \mathrm{~mm}$ - size mish pares to produce bagasse powder (Kamal, 2011).

\section{Animals, housing and experimental design}

The study involved fifty four growing New Zealand White rabbits (NZW) of aged 5 weeks with initial mean weight $751.8 \pm 35.62 \mathrm{~g}$. Animals were divided into nine equal groups. The study lasted two months period (from January till March, 2017), All animals were individually housed in galvanized wire cages $(50 \times 55 \times 39 \mathrm{~cm})$ provided with a feeder and automatic nipple drinker, and were kept under the same managerial means and all animals were weighed weekly.

\section{The experimental design used in vivo experiment}

$\left(\mathbf{T}_{1}\right)$ Basal diet,

( $\left.\mathbf{T}_{2}\right) \quad$ Low dose of AFs $(75 \mu \mathrm{g}$ total AFs $/ \mathrm{kg}$ diet $)$

$\left(\mathbf{T}_{\mathbf{3}}\right) \quad$ High dose of AFs $(150 \mu \mathrm{g}$ total AFs/kg diet $)$

$\left(\mathbf{T}_{4}\right) \quad$ Received basal diet supplemented with bagasse at level 3\%

$\left(\mathbf{T}_{\mathbf{5}}\right)$ Received basal diet supplemented with bagasse at level 6\%

( $\left.\mathbf{T}_{\mathbf{6}}\right)$ Low dose of AFs+ bagasse at level 3\%

$\left(\mathbf{T}_{7}\right)$ Low dose of AFs+ bagasse at level $6 \%$

(T) High dose of AFs+ bagasse at level 3\%

( $\left.\mathbf{T}_{\mathbf{9}}\right)$ High dose of AFs+ bagasse at level $6 \%$

\section{Experimental diet}

The ingredients of each diet which were assigned to each group are shown in Table 1. Prepared diets were kept in jute sack for offering to each animal group.

\section{Growth performance}

Live performance measurements for each feeding period were measured and/or calculated in terms of live body weight (LBW), body weight gain (BWG), feed intake (FI), feed conversion ratio (FCR), performance index (PI) and Mortality rate (MR).

Individual LBWG for each rabbit was calculated at 2, 4, 6, 8, 10 and 12 of experimental period by subtracting the initial LBW of a certain period from the final LBW of the same period, as follows:-

$$
\mathrm{LBWG}=\mathrm{W}_{2}-\mathrm{W}_{1}
$$


Table (1). Composition of ingredient feed rations for control and treated groups.

\begin{tabular}{lccc}
\hline Ingredients & Control & $\mathbf{T}_{\mathbf{4}}$ & $\mathbf{T}_{\mathbf{5}}$ \\
\hline Alfaalfa & 25.00 & 23.00 & 20.00 \\
Wheat bran & 26.00 & 26.00 & 25.00 \\
Barley grains, Ground & 20.00 & 20.00 & 20.00 \\
Soybean meal (44\% CP) & 13.50 & 14.00 & 15.00 \\
Yellow corn, ground & 10.00 & 10.00 & 10.00 \\
Wheat straw & 1.50 & - & - \\
Bagasse & 0.0 & 3.00 & 6.00 \\
L- Methionine & 0.35 & 0.35 & 0.35 \\
Lime stone & 0.9 & 0.9 & 0.9 \\
Di calcium phosphate & 1.9 & 1.9 & 1.9 \\
Premix* & 0.50 & 0.50 & 0.50 \\
Na Cl & 0.35 & 0.35 & 0.35 \\
\hline Total (kg) & $\mathbf{1 0 0}$ & $\mathbf{1 0 0}$ & $\mathbf{1 0 0}$ \\
\hline Calculated values** & & & \\
\hline Crude protein \% & 17.11 & 17.24 & 16.93 \\
DE, kcal/kg diet & 2520 & 2513 & 2490 \\
Crude fiber \% & 11.97 & 11.59 & 12.14 \\
Ether extract \% & 2.54 & 2.50 & 2.41 \\
Calcium \% & 1.17 & 1.15 & 1.11 \\
Available phosphorus & 0.36 & 0.36 & 0.36 \\
Lysine \% & 0.87 & 0.87 & 0.86 \\
Methionine & 0.60 & 0.60 & 0.60 \\
Cost/kg of diet in L.E. *** & 2.73 & 2.38 & 2.31 \\
\hline The premix (Vit. \& Min. & was & & \\
\hline
\end{tabular}

"The premix (Vit. \& Min.) was added at a rate of $3 \mathrm{~kg}$ per ton of diet and supplied the following per $\mathrm{kg}$ of diet (as mg or I.U. per kg of diet): Vit. A 12000 I.U., Vit. D3 2000 I.U., Vit. E $40 \mathrm{mg}$, Vit. K3 $4 \mathrm{mg}$, Vit. B1 $3 \mathrm{mg}$, Vit. B2 $6 \mathrm{mg}$, Vit. B6 4 $\mathrm{mg}$, Vit. B12 $0.03 \mathrm{mg}$, Niacine $30 \mathrm{mg}$, Biotine $0.08 \mathrm{mg}$, Pantothenic Acid $12 \mathrm{mg}$, Folicacid $1.5 \mathrm{mg}$, Choline chloride $700 \mathrm{mg}, \mathrm{Mn} 80 \mathrm{mg}, \mathrm{Cu} 10 \mathrm{mg}$, Se $0.2 \mathrm{mg}$, I 40 $\mathrm{mg}, \mathrm{Fe} 40 \mathrm{mg}$, Zn $70 \mathrm{mg}$ and Co $0.25 \mathrm{mg}$.

**A According to Feed Composition Tables for animal \& poultry feedstuffs used in Egypt (2001) and NRC (1994).

****According to market prices of the year 2017.

Where: $\mathrm{W}_{1}=\mathrm{LBW}$ at the onset of a certain period, $\mathrm{W}_{2}=\mathrm{LBW}$ at the end of the same period.

Feed intake for each replicate under each treatment was weekly calculated, on a group basis, by subtracting the residual feed from the offered one. Average daily feed intake per rabbit was then calculated by using the following equation: 
FI/rabbit/day $=$ FI / replicate/week / No. of rabbits consumed feed daily during the week period

Feed conversion ratio (FCR) (using the weight of mortality to correct FI data) weekly and whole experimental period was calculated for each replicate under each treatment and calculated as $\mathrm{kg}$ of feed used for producing one $\mathrm{kg}$ of body weight gain as follows:

FCR $=$ Average feed intake $(\mathrm{kg})$ per rabbit/ body weight gain $(\mathrm{kg})$ per rabbit.

Daily mortality was recorded. Weekly mortality rate was calculated for each treatment group by subtracting the final number of live rabbits at the end of a certain period from the initial number of live rabbits at the beginning of the same period. Mortality rate percentage was calculated as a number of dead rabbits at the end of a certain period relative to the initial number of live rabbits at the onset of the same period.

\section{Analytical methods}

The proximate chemical analyses of experimental diets and dried feces were performed for moisture, dry matter (DM), organic matter (OM), crude protein $(\mathrm{CP})$, crude fiber $(\mathrm{CF})$, ether extract $(\mathrm{EE})$ and Ash according to the Association of Official Analytical Chemists (AOAC, 2016). Nitrogen free extract (NFE) of both feed and feces was determined using the following equation:

$$
\mathrm{NFE}=100-(\mathrm{CP} \%+\mathrm{EE} \%+\mathrm{CF} \%+\mathrm{Ash} \%) .
$$

\section{Digestibility trials}

Digestion trials were conducted at the end of growth trial to determine the digestibility values and nutritive value of the experimental diets expressed as total digestible nutrients (TDN \%) and digestible crude protein (DCP \%). Three animals representing each group were individually housed in metabolic cages equipped with a stainless- steel screen and $4 \mathrm{~mm}$ mesh to retain feces but allow free passage of urine. Feed and water intake were offered to rabbits ad-libitum during the digestion trial. The digestion trial lasted for 10 days as preliminary period while the collection period lasted for 5 days in which feces was collected daily before the morning meal, weighed fresh and sprayed with $2 \%$ boric acid for trapping any ammonia released from feces and dried at $60{ }^{\circ} \mathrm{C}$ for $24 \mathrm{hrs}$ in an air drying oven. The feces were then ground and mixed, stored for subsequent chemical analysis. Samples of diets and feces were chemically analyzed to determine the digestibility coefficients and nutritive values of the experimental diets. 


\section{Blood parameters}

Blood samples were collected from each rabbit (3 rabbits /group) into dry clean tubes containing heparin and centrifuged at $3000 \mathrm{rpm}$ for $15 \mathrm{~min}$. The plasma was collected and stored at $-20^{\circ} \mathrm{C}$ to estimate some blood constituents as total protein (Armstrong and Corri, 1960), albumin (Doumas et al., 1971), transaminase (aspartate aminotransferase (AST) and alanine aminotransferase (ALT)) (Reitman and Frankel, 1957), triglycerides (Royer and Ko, 1969), cholesterol (Zlatkis et al., 1953), urea nitrogen and creatinine. The globulin values were obtained by subtracting the albumin values from the corresponding values of total proteins.

\section{Organs weights:}

Rabbits were scarified at the end of experiment and the liver and kidney were immediately removed and weighed.

\section{Economic efficiency}

Economic efficiency was calculated by the following equation:

Economic efficiency $=$ (Selling price of one $\mathrm{Kg}$ live body weight - feeding cost of one $\mathrm{Kg}$ live body weight/ Feeding cost of one $\mathrm{Kg}$ live body weight) $\times 100$.

\section{Statistical analysis}

The obtained data were statistically analyzed according to statistical analysis system (SAS, 2003). Data of live body weight, live body weight gain, feed intake, feed conversion and performance index were analyzed using one way analysis of variance according to the following model.

$$
Y_{i j}=\mu+T_{i}+E_{i j} \text {, }
$$

Where, $Y_{i j k}$ is the observation of the parameters measured, $\mu$ is the population mean, $T_{i}$ is effect of adding levels of aflatoxin and bagasse and $E_{i j}=$ experimental error and assumed to be independently and normally distributed with zero mean and $\sigma^{2}$.

Duncan's Multiple Range Test (Duncan, 1955) distinguished the differences among means. Significant level was set at 5\%.

\section{RESULTS AND DISCUSSION}

\section{Chemical composition of experimental diets}

\section{The concentration of the active constituents of Bagasse}

Results of proximate composition of bagasse used for preparation experimental diets $(\mathrm{g} / 100 \mathrm{~g}$ dry matter) presented in Table 2 . Cleared that ground bagasse used in the present study contains $2.1 \% \mathrm{CP} ; 34.4 \% \mathrm{CF}$ 
Table 2. Proximate composition of bagasse used for preparation of dietary

\begin{tabular}{cc}
\multicolumn{1}{c}{ fiber } & \\
\hline Items & Proximate analysis $(\mathbf{g} / \mathbf{1 0 0}$ g on dry matter basis) \\
\hline Protein & 2.1 \\
Fiber & 34.4 \\
Ash & 1.38 \\
Cellulose & 37.08 \\
Hemicelluloses & 21.25 \\
Lignin & 6.42 \\
Silica & 1.0 \\
NDF & 65.97 \\
ADF & 44.72 \\
ADL & 7.64 \\
\hline
\end{tabular}

and little concentration of ash (1.38\%) meanwhile the main components in bagasse proximate analysis are cellulose (37.08\%); Hemiclose $(21.25 \%)$ and lignin $(6.42 \%)$. Therefore, sugarcane bagasse has been successfully used as a fibre source for animal and rabbits diets. Also, bagasse is a good source of lignoceric and cerotic acids (Kamal, 2011).

\section{Chemical composition of tested diets}

Chemical compositions (Proximate Analysis) of experimental rations are presented in Table 3.

Table 3. Chemical compositions (Proximate Analysis) of Experimental rations.

\begin{tabular}{llllllllll}
\hline Items & $\begin{array}{l}\text { DM } \\
\%\end{array}$ & $\begin{array}{l}\text { Moisture } \\
\text { \% }\end{array}$ & $\begin{array}{l}\text { OM } \\
\text { \% }\end{array}$ & $\begin{array}{l}\text { CP } \\
\text { \% }\end{array}$ & $\begin{array}{l}\text { CF } \\
\text { \% }\end{array}$ & $\begin{array}{l}\text { EE } \\
\text { \% }\end{array}$ & $\begin{array}{l}\text { NFE } \\
\text { \% }\end{array}$ & $\begin{array}{l}\text { Ash } \\
\text { \% }\end{array}$ & $\begin{array}{l}\text { DE } \\
(\text { Mcal/kg) }\end{array}$ \\
\hline Ration1 & 89.27 & 10.73 & 80.82 & 16.94 & 10.94 & 2.65 & 50.29 & 8.45 & 2.59 \\
Ration4 & 88.79 & 11.21 & 81.05 & 16.56 & 10.49 & 2.24 & 51.76 & 7.74 & 2.61 \\
Ration5 & 89.82 & 10.18 & 82.09 & 16.49 & 11.46 & 1.54 & 52.6 & 7.73 & 2.57 \\
\hline
\end{tabular}

$* \mathrm{DE}(\mathrm{Mcal} / \mathrm{kg})=4.36-0.049 \times \mathrm{NDF}, \mathrm{NDF} \%=28.924+0.657$ (CF \%) according to Cheeke (1987).

\section{Productive performance}

Results in Table 4 showed that the initial body weight was in average of $751.8 \pm 35.62 \mathrm{~g}$. Live body weight at 13 week of age of rabbits fed basal diet supplemented with bagasse at level 6\% with low or high dose of aflatoxin (T7 and T9) recorded numerically higher body weight value (2220.8 and $2204 \mathrm{~g}$ ) compared to control group (T1) (2087 g) and rabbits groups fed basal diet 


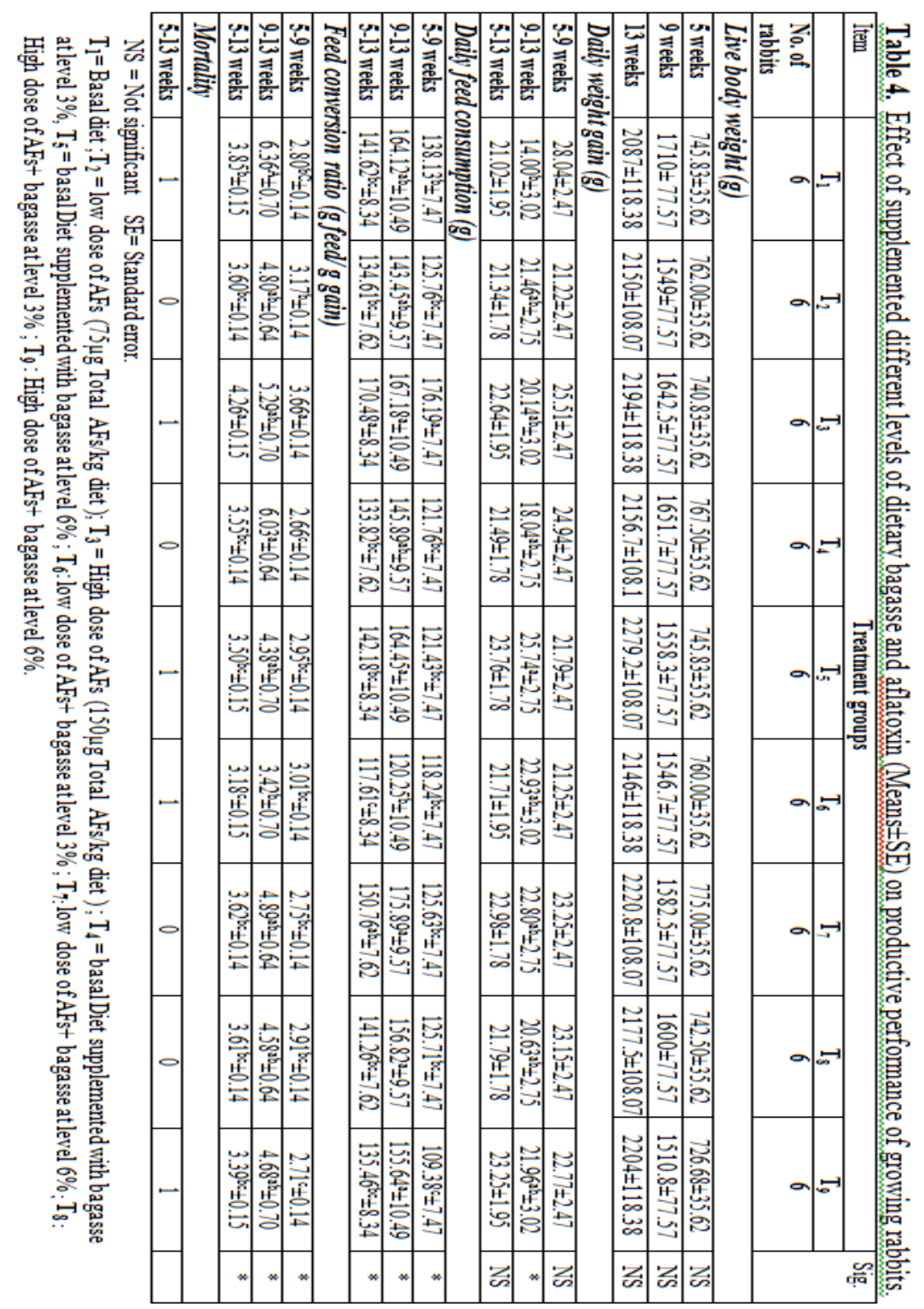


supplemented with low and high dose of aflatoxin (T2 and T3). Also, rabbits fed basal diet supplemented with bagasse at level $3 \%$ and $6 \%$ without aflatoxin recorded higher live body weight value but not significant compared to control group (T1). The same trend was observed for daily weight gain. These results are in close to Ismail et al. (2016) who reported that the final body weight and feed intake of rabbits increased with increasing levels of sugarcane bagasse. In this connection, SUN et al. (2018) found that during the first $3 \mathrm{wk}$. and week 7, the supplementation of aflatoxin B1 did not affect bucks' live body weight (LBW). Table 4 presented that rabbits fed high dose of aflatoxin (T3) recorded significantly $(\mathrm{P}<0.05)$ the highest daily feed consumption during 5-9 and 5-13 weeks compared to control and other groups. The best significant $(\mathrm{P}<0.05)$ value of the feed conversion ratio was recorded with rabbit fed basal diet supplemented with $3 \%$ bagasse and low dose of aflatoxin (T6) at 9-13 weeks of age and the whole experiment period compared to rabbits fed basal diet with low dose of aflatoxin (T2). While rabbits fed basal diet supplemented with $6 \%$ bagasse and high dose of aflatoxin (T9) recorded the best significant $(\mathrm{P}<0.05)$ value of the feed conversion ratio compared to rabbits fed basal diet with high dose of aflatoxin (T3). Also, rabbits fed basal diet with bagasse 3\% or 6\% (T4 and T5) showed significant $(\mathrm{P}<0.05)$ best value of feed conversion compared to control group (T1). Valchev et al. (2017) indicated that compound feed supplementation with increased amounts of aflatoxin B1 $(0.2 \mathrm{mg} / \mathrm{kg}$ or 0.4 $\mathrm{mg} / \mathrm{kg}$ ) significantly reduced live weight, weight gain and feed intake and thus increased feed conversion. The same trend is observed by Zuo et al. (2013) and Chibanga et al. (2014) who stated that consumption of feed contaminated with low amount of aflatoxins in broiler chickens significantly degraded growth performance. Death losses during entire experimental period either for group fed on basal diet or the groups fed basal diet supplemented by bagasse with or without aflatoxin were observed (Table 4). Maidala et al. (2016) concluded that sugarcane bagasse can be used as a source of fiber in the diets of growing rabbits without deleterious effect with reduction in cost of production.

\section{Nutrients digestibility, Nutritive values and nitrogen balance}

Digestibility coefficients of nutrients and nutritive values are presented in Table 5. Results indicated a significant differences $(\mathrm{P}<0.05)$ among DM, OM, CP, CF, EE and NFE digestibility for all treatments. The values of DM, OM, CP, EE and NFE for rabbits group fed basal diet supplemented with bagasse at level $6 \%\left(\mathrm{~T}_{5}\right)$ were the highest ones; being $67.86,68.43,72.13,53.01$ and 76.54 , respectively compared to control 


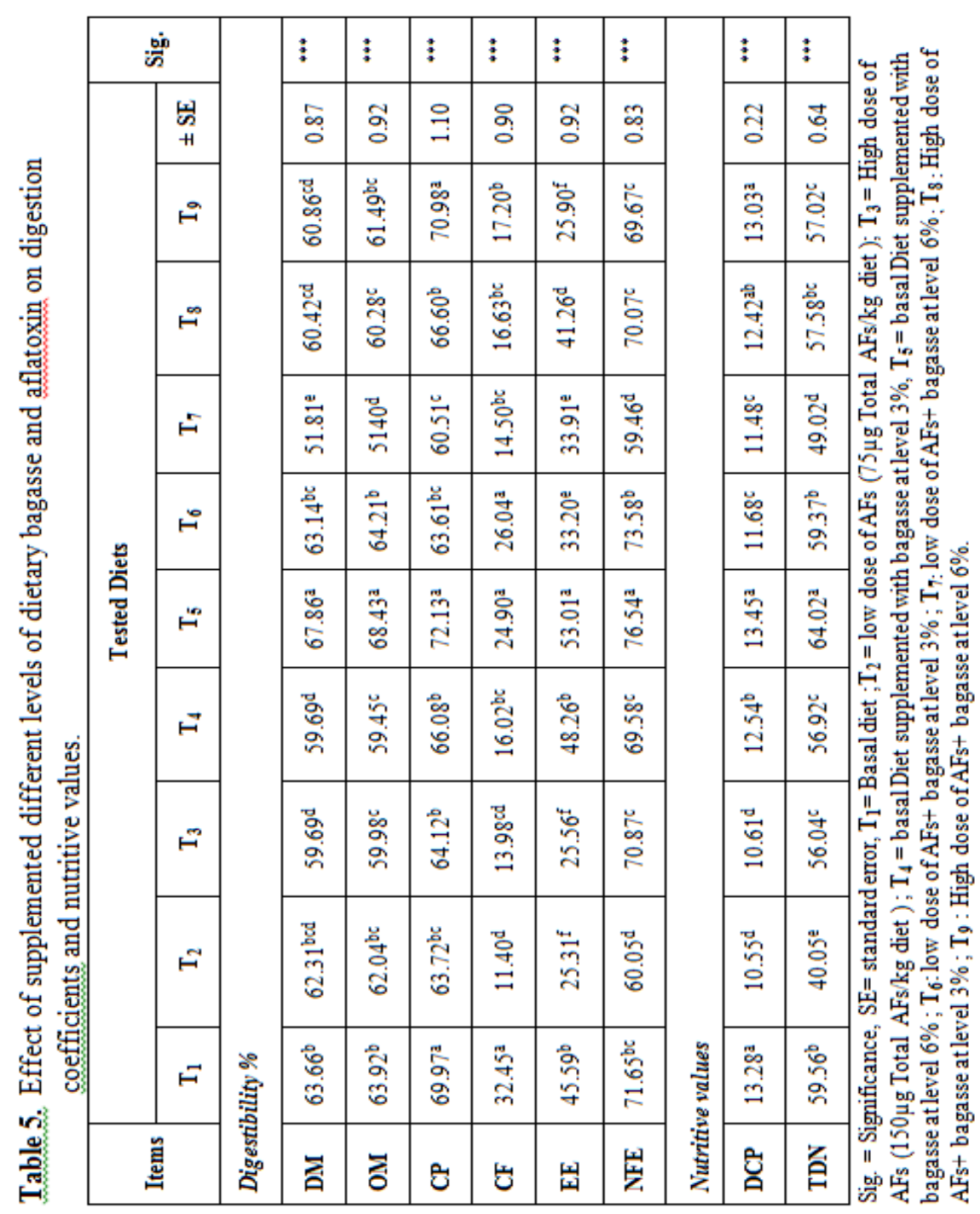


group $\left(\mathrm{T}_{1}\right)(63.66,63.92,69.97,45.59$ and 71.65 , respectively) and rabbits group fed $3 \%$ bagasse $\left(\mathrm{T}_{4}\right)$. The $\mathrm{CF}$ value for control group was the highest compared to the other experimental groups. These results are consistent with Babiker et al. (2016) who found that, the digestibility of crude protein and organic matter of the sugarcane bagasse were improved $(\mathrm{P}<0.05)$ in experimental diets. in general, rabbits fed 3\% bagasse with low dose of aflatoxin $\left(\mathrm{T}_{6}\right)$ recorded significantly $(\mathrm{P}<0.05)$ higher values of digestibility nutrients, DCP and TDN compared to rabbits fed basal diet with low dose of aflatoxin $\left(\mathrm{T}_{2}\right)$. While, rabbits fed $6 \%$ bagasse with high dose of aflatoxin $\left(\mathrm{T}_{9}\right)$ recorded significantly $(\mathrm{P}<0.05)$ higher values of digestibility nutrients, DCP and TDN compared to rabbits fed basal diet with high dose of aflatoxin $\left(\mathrm{T}_{3}\right)$ indicating positive influential effect of bagasse.

\section{Blood constituents}

Blood plasma biochemical analysis values are used as indicators of the health status of rabbits. Table 6 represent the changes in serum total protein (TP), and albumin (ALb) of rabbits treated with two doses low and high aflatoxins $\left(\mathrm{T}_{2}\right.$ and $\left.\mathrm{T}_{3}\right)$ caused a significant decrease in both values when compared with control group $\left(\mathrm{T}_{1}\right)$. Supplementation of $3 \%$ and $6 \%$ bagasse with low and high doses of aflatoxins ( $\mathrm{T}_{6}$ to $\mathrm{T}_{9}$ ) showed a significant increase in both parameters when compared to groups treated with aflatoxins singly $\left(T_{2}\right.$ and $\left.T_{3}\right)$. The highest value of serum protein and albumin were obtained on treatment with low aflatoxins dose and $6 \%$ supplementation of bagasse (6.10, and $3.5 \mathrm{~g} / \mathrm{dl}$, respectively). These results are in agreement with Nwaogu (2016) and Barati et al. (2018) who found that total proteins were decreased in poultry as a result of feeding with aflatoxins contaminated diets. This led to damage in liver health and disturbance in metabolic pathways.

Regarding to creatinine and urea, Table 6 showed that significant increase in values of serum creatinine and urea of rabbits fed on low and high doses of aflatoxins $\left(\mathrm{T}_{2}\right.$ and $\left.\mathrm{T}_{3}\right)$ when compared with control group $\left(\mathrm{T}_{1}\right)$. Supplementation of $3 \%$ and $6 \%$ bagasse in groups $\mathrm{T}_{4}$ and $\mathrm{T}_{5}$ showed no effects in both parameters when compared to control group $\left(T_{1}\right)$. Groups of rabbits treated with low and high doses of aflatoxin and with $3 \%$ and $6 \%$ bagasse $\left(T_{6}\right.$ to $\left.T_{9}\right)$ showed a significant decrease in both parameters when compared to groups treated with aflatoxins singly $\left(\mathrm{T}_{2}\right.$ and $\left.\mathrm{T}_{3}\right)$. The results showed the lowest value of serum creatinine and urea obtained with low dose of aflatoxins and $6 \%$ bagasse supplementation $(0.87$, and $27.67 \mathrm{mg} / \mathrm{dl}$, respectively). 
USINGBAGASSE AS A SOURCE OF NATURAL FIBER INGREDIENT IN RABBITS 137

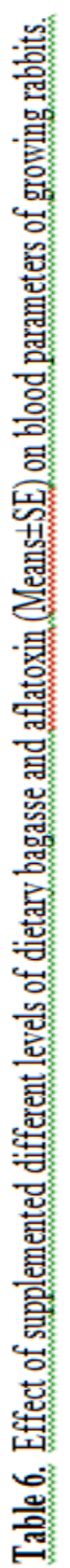

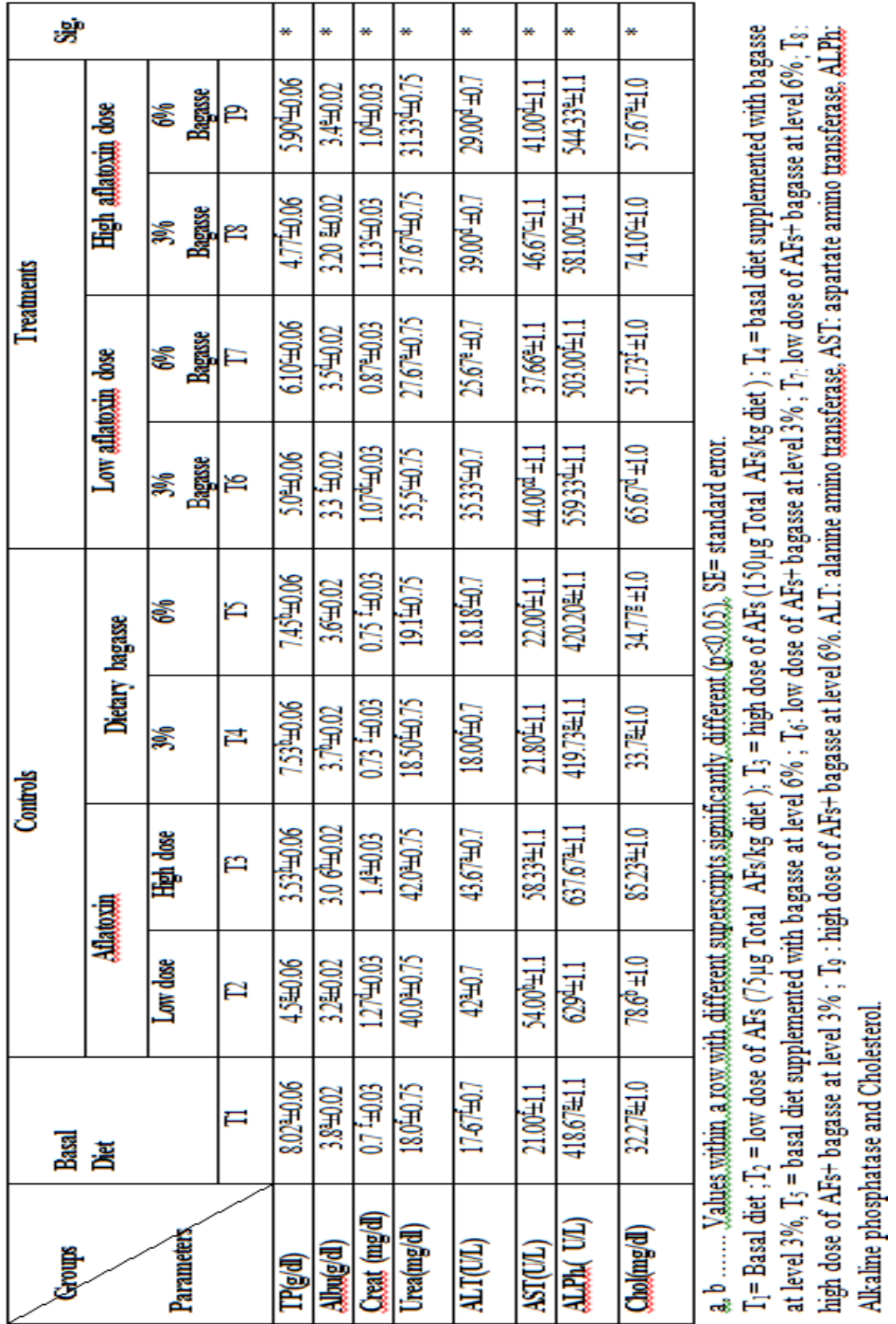


In this regard, increased creatinine and urea in the blood indicate inflammatory changes in the kidneys. These results are consistent with

In this regard, increased creatinine and urea in the blood indicate inflammatory changes in the kidneys. These results are consistent with ElDesouky et al. (2017) and Al-Masri (2017) who observed high levels of creatinine and uric acid when rats fed with wheat contaminated with $\mathrm{AFB}_{1}$ as compared with the control group.

The results of Table 6 showed no significant $(\mathrm{P}<0.05)$ changes noticed in ALT, AST, ALP activities in rabbits treated with bagasse alone at level $3 \%$ and $6 \%$ for groups $\left(\mathrm{T}_{4}\right.$ and $\left.\mathrm{T}_{5}\right)$ in all experiment period corresponding to control group $\left(\mathrm{T}_{1}\right)$. Rabbits fed on basal diet supplemented with $\% 6$ bagasse and aflatoxin with low and high concentration $\left(\mathrm{T}_{7}\right.$ and $\left.\mathrm{T}_{9}\right)$ showed a significant decrease in serum ALT, AST, ALP activity and cholesterol comparing with basal diet supplemented with aflatoxin (low and high concentration) without bagasse $\left(T_{2}\right.$ and $\left.T_{3}\right)$. These results almost were in agreement with Hasan (2014) who found an increase in serum levels of ALT, AST and ALP in rats treated with aflatoxins during storage of walnuts. This also agrees with Abdel-Wahhab et al. (2014) who reported that an increase in ALT and AST in aflatoxin-treated rats was an indication of changes in liver tissue.

\section{Economic efficiency}

The effect of different levels of dietary bagasse on the average values of economical efficiency is presented in Table 7. Generally, among the most important factors involved in the achievement of maximum efficiency in meat production are feeding cost, length of growing period and the final body weight. Accordingly, the economic efficiency of any product could be calculated from input_output analysis based mainly up on the total feeding cost per total number of Kg LBW sold and the current selling price of LBW per Kg (Hala, 1998).

It should be pointed out that the calculation herein depended on the average price at 2017 (during which the experiment was executed). Results showed an improvement in the average values of net revenue, economical efficiency and relative economical efficiency due to feeding growing rabbits the diets with $6 \%$ bagasse without aflatoxin $\left(\mathrm{T}_{5}\right.$ ) (being $58.65 ; 2.30$ and 122.34 , respectively) compared to control group $\left(\mathrm{T}_{1}\right)$ and $3 \%$ bagasse group $\left(\mathrm{T}_{4}\right)$. It can be noticed that, low and high aflatoxin dose $+6 \%$ of bagasse diet $\left(\mathrm{T}_{7}\right.$ and $\left.\mathrm{T}_{9}\right)$ recorded the best relative economic efficiency $\%$ (120.21 and $119.04 \%)$ compared to $\mathrm{T}_{2}, \mathrm{~T}_{3}, \mathrm{~T}_{6}$ and $\mathrm{T}_{8}(105.85,103.03,110.77$ and $109.09 \%)$. These decreasing in relative economic efficiency $\%$ may be due 
USING BAGASSE AS A SOURCE OF NATURAL FIBER INGREDIENT IN RABBITS 139

\begin{tabular}{|c|c|c|c|c|c|c|c|c|c|c|c|c|}
\hline & 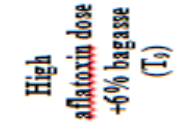 & & $\equiv$ & ప్ర & בa & 导 & $\therefore$ & 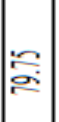 & 语 & 至葛 & $\mid$\begin{tabular}{ll}
0 & 0 \\
\hdashline & 9 \\
0 & 9
\end{tabular} & \\
\hline & 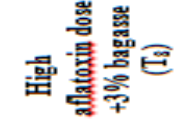 & & 㤩 & ঞ & 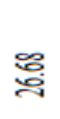 & 哭 & $\therefore$ & $\vec{\Sigma}$ & 突 & 家递 & 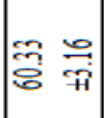 & \\
\hline & 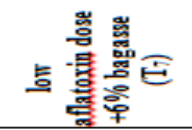 & & 욱 & $\underset{7}{\not}$ & త్రి & $\Xi$ & $\therefore$ & $\approx$ & ঞ্নি & $\approx$ ন & 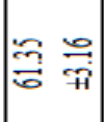 & \\
\hline 흘 & 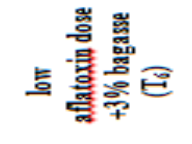 & & 䓌 & $\stackrel{\leftrightarrow}{\leftrightarrow}$ & 总 & $\Xi$ & $\therefore$ & $=$ & ్ㅗㄱ곡 & 号 & $\mid \begin{array}{ll}9 \\
0 \\
0\end{array}$ & 危 \\
\hline 党 & 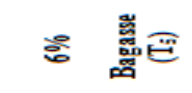 & & הి & ప్ర & : & $\Xi$ & $\therefore$ & 帮 & 通 & 吾 & 耺亭 & 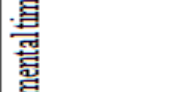 \\
\hline & 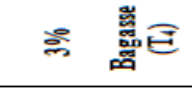 & & 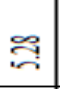 & \& & 号 & 年 & $\therefore$ & 总 & 总 & $\approx$ & 응 & 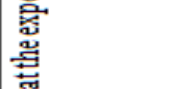 \\
\hline & 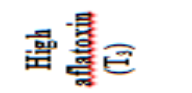 & & ః & s; & 产 & 요= & $\therefore$ & 悉 & 콩 & 至 & 兽 & 壹 总 \\
\hline & 点咢 & & $\stackrel{\infty}{\varrho}$ & क्ष & 壱 & 욤 & $\therefore$ & 璦 & 흥 & S: & 도요. & \\
\hline & 咅 & & 冾 & ga & 祢 & $\approx$ & $\therefore$ & 高 & 兴 & $\approx$ & 豆㕝 & \\
\hline & 器 & 荧 & 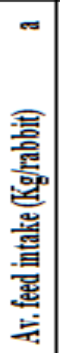 & 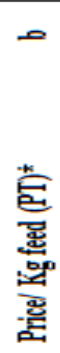 & 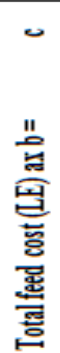 & 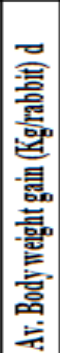 & 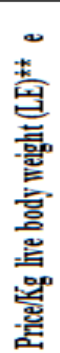 & 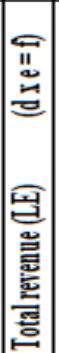 & 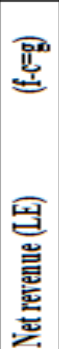 & 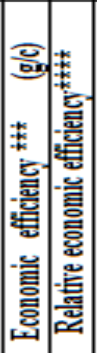 & 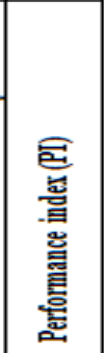 & 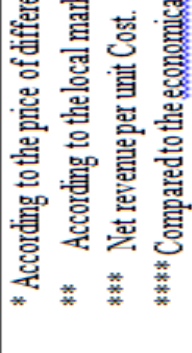 \\
\hline
\end{tabular}


to bad effect of aflatoxin dose which caused increasing in feed intake and decreasing in final live body weight gain.

Results of performance index (PI) are presented in Table 7. The results indicated that the highest value of total PI recorded for rabbits group fed low dose of aflatoxin+ bagasse at level 3\% $\left(\mathrm{T}_{6}\right)$ followed by rabbits group fed bagasse at level 6\% $\left(\mathrm{T}_{5}\right)$ (67.48 and 65.11, respectively). While, the worst value was recorded by rabbits group fed high dose of AFs $\left(\mathrm{T}_{3}\right)$ $(51.5 \%)$.

The results present in Table 8 show that, rabbits groups treated with low and high doses of aflatoxins $\left(\mathrm{T}_{2}\right.$ and $\left.\mathrm{T}_{3}\right)$ achieved significant increase in liver, and kidney weight mainly at the end of the experimental period, compared with control group $\left(\mathrm{T}_{1}\right)$. That could be a result of inflammatory and biochemical changes due to the presence of aflatoxins in these organs.

Table 8 . Liver and Kidney weight of growing rabbits as affected by different levels of dietary bagasse $(\mathrm{Means} \pm \mathrm{SE})$.

\begin{tabular}{|c|c|c|c|c|c|c|c|c|c|c|}
\hline \multirow{4}{*}{$\begin{array}{l}\text { Groups } \\
\text { Parameters }\end{array}$} & \multirow{3}{*}{$\begin{array}{l}\text { Basal } \\
\text { Ditat }\end{array}$} & \multicolumn{4}{|c|}{ Controks } & \multicolumn{4}{|c|}{ Treatment } & \multirow[t]{4}{*}{ Sig. } \\
\hline & & \multicolumn{2}{|c|}{ Aftatoin } & \multicolumn{2}{|c|}{ Bagasse } & \multicolumn{2}{|c|}{ Low aflatoxin dose } & \multicolumn{2}{|c|}{ High aftatoin dose } & \\
\hline & & $\begin{array}{l}\text { Low } \\
\text { dose }\end{array}$ & $\begin{array}{l}\text { High } \\
\text { dose }\end{array}$ & $3 \%$ & $6 \%$ & $\begin{array}{c}3 \% \\
\text { Bagasse }\end{array}$ & $\begin{array}{c}6 \% \\
\text { Bagasse }\end{array}$ & $\begin{array}{c}3 \% \\
\text { Yagasse }\end{array}$ & $\begin{array}{c}6 \% \\
\text { Bagasse }\end{array}$ & \\
\hline & $\mathrm{Tl}$ & $\mathrm{T} 2$ & $\mathrm{~T} 3$ & $\mathrm{T4}$ & T5 & T6 & 17 & T8 & $\mathrm{T} 9$ & \\
\hline Liver weght & $\begin{array}{l}5334^{4} \\
\pm 3.73\end{array}$ & $\begin{array}{l}94.55^{b} \\
\pm 3.73\end{array}$ & $\begin{array}{c}140.93^{2} \\
\pm 3.73\end{array}$ & $\begin{array}{l}5726^{\mathrm{d}} \\
\pm 3.73\end{array}$ & $\begin{array}{l}65255^{\star} \\
\pm 3.73\end{array}$ & $\begin{array}{c}68.06^{\text {ct }} \\
\pm 3.73\end{array}$ & $\begin{array}{l}66.49^{9 c^{c t}} \\
\pm 3.73\end{array}$ & $\begin{array}{l}77.1 x^{x} \\
\pm 3.73\end{array}$ & $\begin{array}{l}77.07^{\star} \\
\pm 3.73\end{array}$ & - \\
\hline $\begin{array}{l}\text { Kidney } \\
\text { weight }\end{array}$ & $\begin{array}{l}8.71^{d} \\
\pm 1.15\end{array}$ & $\begin{array}{l}18.51 \text { a } \\
\pm 1.15\end{array}$ & $\begin{array}{r}20.35^{2} \\
\pm 1.15\end{array}$ & $\begin{array}{l}12.69^{d} \\
\pm 1.15\end{array}$ & $\begin{array}{l}14.10^{ \pm} \\
\pm 1.15\end{array}$ & $\begin{array}{c}14,81 \text { tad } \\
\pm 1,15\end{array}$ & $\begin{array}{l}14.38^{\alpha} \\
\pm 1.15\end{array}$ & $\begin{array}{l}17.0^{332 x} \\
\pm 1.15\end{array}$ & $\begin{array}{c}15.45^{\text {tod }} \\
\pm 1.15\end{array}$ & . \\
\hline
\end{tabular}

a. b ...... Values within a row with different superscripts significantly different ( $\mathrm{P}<\mathrm{Q}(05)$.

$\mathrm{SE}=$ standard error.

$\mathrm{T}_{1}=$ Basal diet $; \mathrm{T}_{2}=$ low dose of $\mathrm{AFs}(75 \mu \mathrm{g}$ Total $\mathrm{AFs} / \mathrm{kg}$ diet $) ; \mathrm{T}_{3}=$ High dose of AFs $(150 \mu \mathrm{g}$ Total AFs $/ \mathrm{kg}$ diet ); $T_{4}=$ basal diet supplemented with bagasse at level $3 \%, T_{5}=$ basal diet supplemented with bagasse at level $6 \% ; \mathrm{T}_{6}$ : low dose of $\mathrm{AFs}+$ bagasse at level $3 \% ; \mathrm{T}_{7}$ : low dose of $\mathrm{AFs}+$ bagasse at level $6 \% ; \mathrm{T}_{8}$ : High dose of $\mathrm{AFs}+$ bagasse at level $3 \% ; \mathrm{T}_{9}$ : High dose of AFs + bagasse at level $6 \%$.

Conclusively, based on the results obtained in this study, it was established that using $6 \%$ of bagasse only without aflatoxin in the rations of growing rabbit's achieved improvements in growth performance parameters, digestibility coefficients, biochemical parameters and economic efficiency. At the same time, presence of bagasse alleviated the detrimental effect of aflatoxin. 


\section{REFERENCES}

Abdel-Wahhab, M.A.; E. S. El-Denshary; A. A. El-Nekeety, N. S. Hassan; F. M. Abu-Salem; N. A. Sarhan and B. H. Rhin (2014). Impact of Soy Isoflavones on Aflatoxin-induced Oxidative Stress and Hepatotoxicity in Rats. General Health and Medical Sciences, 1: 9-14.Sciences Journal $31: 1269-1277$.

Al-Masri, S.A. (2017). Antioxidant activity of ascorbic acid against aflatoxin in contaminated nuts on rats. The Journal of Animal \& Plant Sciences, 27: 389-397.

Almeida G. A. P.; M. A. Ferreira; J. L. Silva; J. C. C. Chagas; A. S. C. Véras; L. J. A. Barros and G. L. P. Almeida (2018). Sugarcane bagasse as exclusive roughage for dairy cows in smallholder livestock system. Asian-Australas. J. Anim. Sci.31:379-385. doi: 10. 5713 / ajas.17.0205.

AOAC. (2016). Official Methods of Analysis International. 20th Ed. Association of Official Agricultural Chemists, Washington, D.C., U.S.A.

Armstrong, W. D. and C. W. Corri (1960). Physiological Chemistry. Laboratory Diction, 3rd Edition, P. 75 Punges publishing Co., Minneapolis, USA.

Avantaggiato, G., M. Solfrizzo and A. Visconti (2005). Recent advances on the use of adsorbent materials for detoxification of Fusarium mycotoxins. Food Addit. Contam. 22, 379-388.

Barati, M.; M. Chamani; S. N. Mousavi; S. A. Hoseini and M. T. A. Ebrahimi (2018). Effects of biological and mineral compounds in aflatoxin-contaminated diets on blood parameters and immune response of broiler chickens. Journal Of Applied Animal Research, 46:707-713.

Barros, R. C. D.; V. R. R. Júnior; A. S. D. Souza; M. Franco; T. D. S. Oliveira; Gustavo Almeida Mendes; D. A. D. A. Pires; E. Sales; L. A. Caldeira (2010). Economic viability of substitution of sorghum silage by sugarcane or sugarcane bagasse ammoniated with urea for cattle in feedlot. Rev Bras Saude Prod Anim., 11:555-69.

Chibanga, J. F.; D. B. Nyirenda and J. Simbaya (2014). Effects of supplementing different levels Vitamin A Aflatoxin B1 contaminated diets on the performance of broiler chickens. Asian Journal of Natural \& Applied Sciences, 3: 35-46.

De Gisi, S.; G. Lofrano; M. Grassi and M. Notarnicola (2016). Characteristics and adsorption capacities of low-cost sorbents for wastewater treatment: A review. Sustain. Mater. Technol., 9, 10-40. 
Doumas, B. T.; W. A. Watson and H. G. Biggs (1971). Albumin standards and the measurement of serum albumin with bromcresol green. Clinica Chimica Acta, 31(1), 87-96.

Duncan, D. B. (1955). Multiple range and multiple F tests. Biometrics, 11:1-42.

El-Desouky, T.A.; A. M. A. Sharoba; A. I. El-Desouky; H. A. El-Mansy and K. Naguib (2017). Biological and Histopathological Evaluations of Using Ozone Gas in Decontamination of Aflatoxin $B_{1}$ in Wheat Grains. MOJ Toxicol, 3:57,1-7.

HÁLA, Jiř́ (1998). Radioaktivita, ionizující záření, jaderná energie. 1. vyd. Brno: Konvoj, 311 s. ISBN 80-85615-56-8.

Hasan, R. H. G. (2014). Acute and Chronic Effects of Aflatoxin on the Liver of Rats During the Storage of Walnuts, World Applied Sciences Journal, $31: 1269-1277$.

Ismail F.S.A.; M. R. Elgogry; W. A. Morsy and H. M. EL-Tahan (2016). Effect of using sugarcane bagasse with or without enzymes in rabbit diets on growth performance of growing rabbits. World Rabbit Science Association Proceedings 11th World Rabbit Congress, June 15-18.

Babiker, I. A.; A. M. S. Mukhtar; O. A. E. Khidir (2016). Digestibility and rumen degradability of bagasse based diets (bbd) fed to beef cattle. $J$ Dairy Vet Anim Res., 3(1):15-18, DOI: 10.15406/jdvar.2016.03.00065.

Kamal, G. Nath (2011). Utilization of sugarcane bagasse fiber in functional food formulations. Master of Science. University of Agricultural Sciences, Bengaluru.

Khadem, A.A.; S. D. Sharifi; M. Barati and M. Borji (2012). Evaluation of the effectiveness of yeast, zeolite and active charcoal as aflatoxin absorbents in broiler diets. Global Vet. 4: 426-432.

Maidala, A. and J. A. Istifanus (2012). The role of micro livestock in alleviating protein deficiency and poverty reduction in Nigeria being a paper presented at the second school of vocational and technical education. National Conference Held at College of Education Azare from $4-8^{\text {th }}$ June.

Maidala, A.; T. N. Dahuwa and J. Haruna (2016). Nutritional Evaluation of Human Used Sugar Cane Bagasse as a Source of Fibre on Growth Performance and Carcass Characteristics of Rabbits. International Journal of Geography and Environmental Management, ISSN 2504-8821 Vol. 2 No.1rabbits. Ind. J. Exp. Biol., 34: 592-593.

NRC (1994). National Research Council.Nutrient Requirements of Poultry. $9^{\text {th }}$ Ed. National Academy of Sciences. Washington, D.C., USA. 
Nwaogu, L. A. (2016). Toxico-pathological evaluation of Citrulluscolocynthis seed and Pulp aqueous extracts on albino rats. World J. Biol. Med. Sci. 3: 76-85.

Reitman, S. and S. A. Frankel (1957). Colorimetric method for the determination of sGOT and sGPT. Amr. J. Clin. Pathol., 28: 56-63.

Royer, M. E. and H. A. Ko (1969). Simplified semi-automated assay for plasma triglycerides. Ann. Biochem. 29:405.

SAS (2003). SAS/STAT User's Guide (Version 9.2). Statistical Analysis System Inst, Cary, NC.

Siqueira, T.C.A.; I. Z. Da Silva; A. J. Rubio; R. Bergamasco; F. Gasparotto; E. A. De Souza Paccola and N. U. Yamaguchi (2020). Sugarcane Bagasse as an Efficient Biosorbent for Methylene Blue Removal: Kinetics, Isotherms and Thermodynamics. Int. J. Environ. Res. Public Health , 17:526; doi:10.3390/ijerph17020526.

Sun, Y.; G. Dong; E. Guangxin; M. Liao; L. Tao and J. Lv (2018). The effects of low levels of aflatoxin B1 on health, growth performance and reproductivity in male rabbits. World Rabbit Science, 26 (2): 123.

Valchev, I.; V. Marutsova; I. Zarkov; A. Ganchev and Y. Nikolov (2017). Effects of aflatoxin B1 alone or co-administered with Mycotox NG on performance and humoral immunity of turkey broilers. Bulgarian Journal of Veterinary Medicine, 20 (1).

Williams, J. H.; T. D. Phillips; P. E. Jolly; J. K. Stiles; C. M. Jolly and D. Aggarwal, (2004). Human aflatoxicosis in developing countries: a review of toxicology, exposure, potential health consequences, and interventions. The American Journal of Clinical Nutrition, 80 (5):11061122, https://doi.org/10.1093/ajcn/80.5.1106.

Zahoor, M. and F. A. Khan (2018). Adsorption of aflatoxin B1 on magnetic carbon nanocomposites prepared from bagasse. Arabian Journal of Chemistry, 11:729-738.

Zlatkis, A.; B. Zak and A. J. Boyle (1953). A new method for the direct determination of serum cholesterol. J. Lab. Clin. Med. 41:486-92, [Depts. Chem., Pathol., and Med., Wayne Univ., and City of Detroit, Receiving Hosp., Detroit, MI].

Zuo, R. Y., J. Chang, Q. Q. Yin, P. Wang, Y. R. Yang, X. Wang, G. Q. Wang and Q. H. Zheng (2013). Effect of the combined probiotics with aflatoxin B2-degrading enzyme on aflatoxins detoxification, broiler production performance and hepatic enzyme gene expression. Food and Chemical Toxicology, 59, 470-475. 
تأثير إستخدام مصاصة القصب كمصدر طبيعى للالياف وكمادة ماصة للأفلاتوكسين في علائق الأرانب النامية على الأداء

\section{حنى السيد أحمد أبو عيد" ـ محمود سعد أبو سكين". . أمل عبد العزيز أبو حجر "*

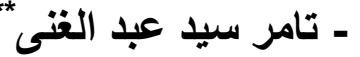

*قشم التتمية المتو اصلة للبيئة و إدارة مشرو عاتها - معهد الدراسات و البحوث البيئية

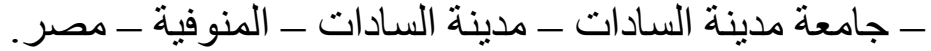

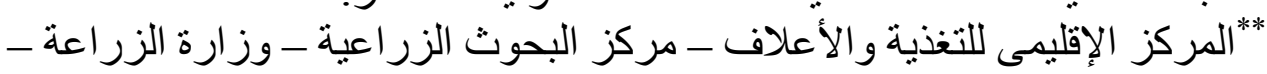

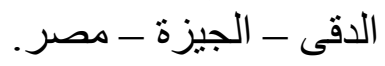

أجريت الدراسة لتحديد أثر إضافة مصاصة القصب كمصدر للألياف الطبيعية

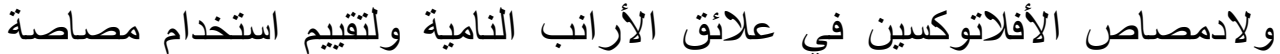

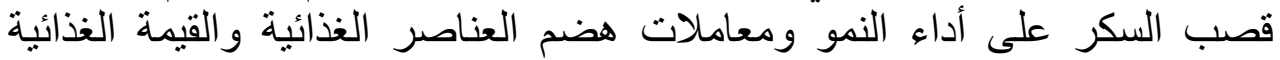
وبعض مكونات الدم والكفاءة الاقتصادية للأرانب النيوزيلندية البعائية البيضاء النامية.

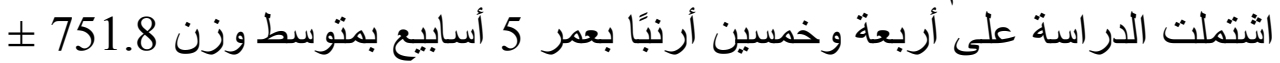

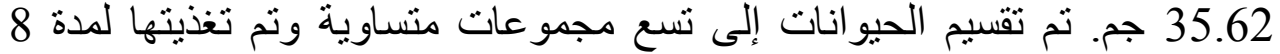

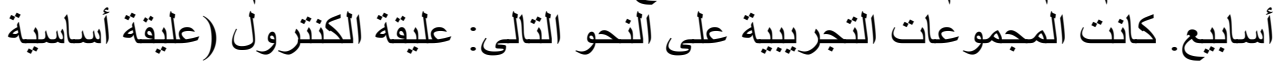

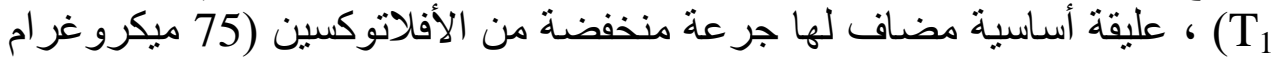

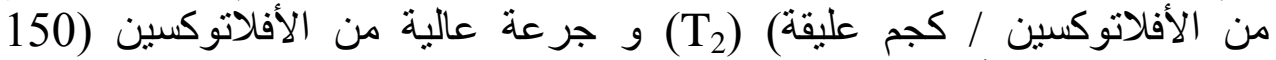

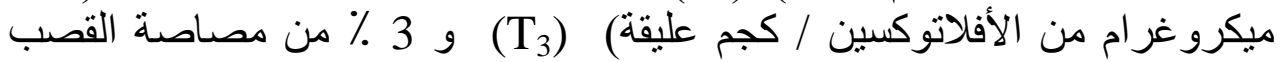

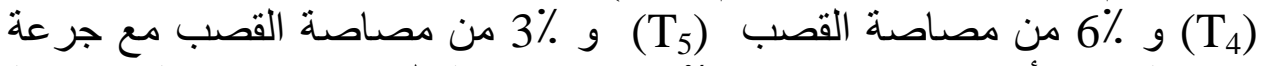

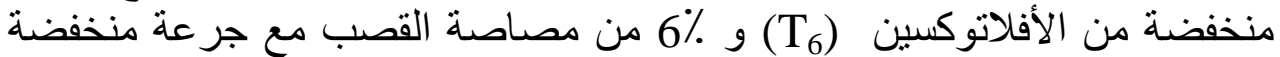
من الأفلاتوكسين (T)

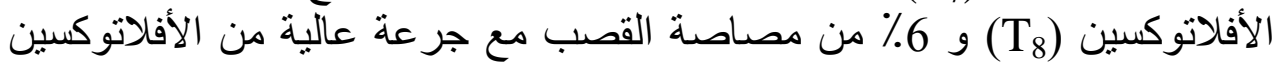

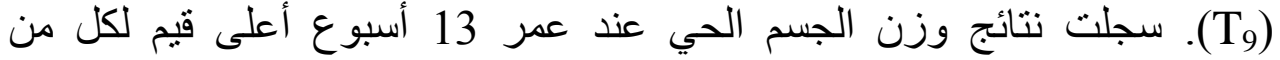

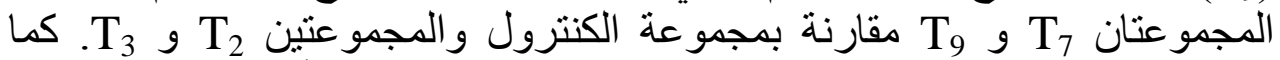

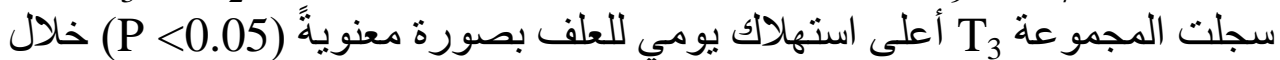

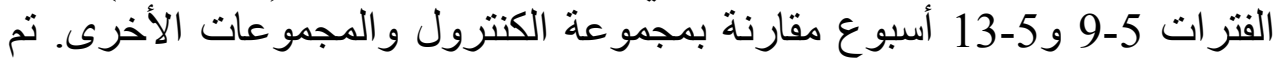

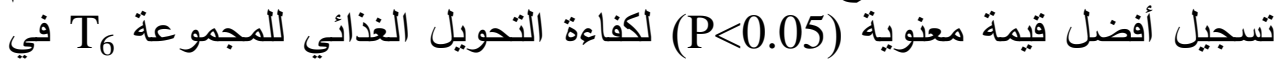

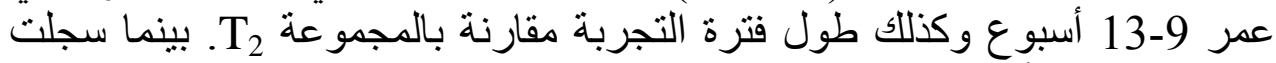

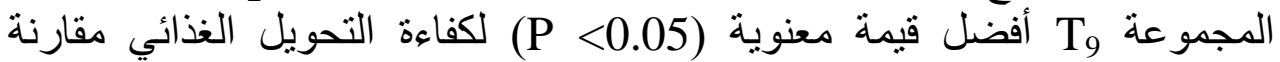


USING BAGASSE AS A SOURCE OF NATURAL FIBER INGREDIENT IN RABBITS 145

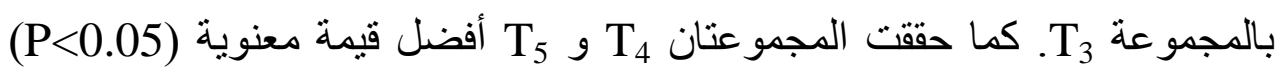

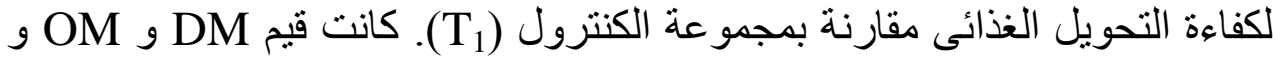
NFE و EE و CP

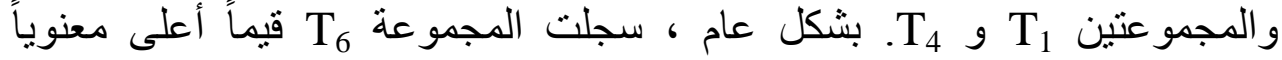

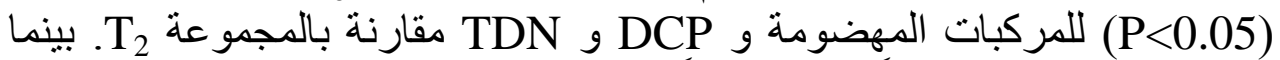

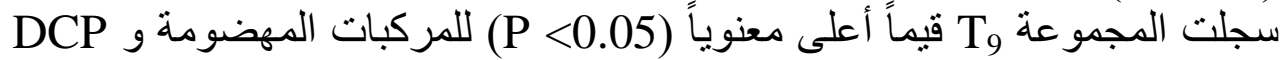

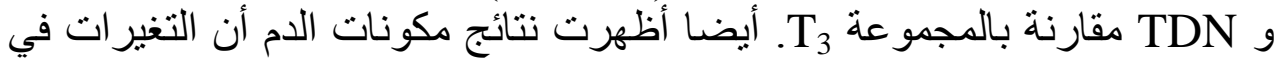

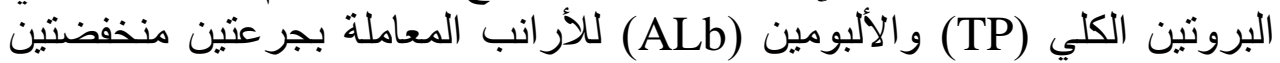

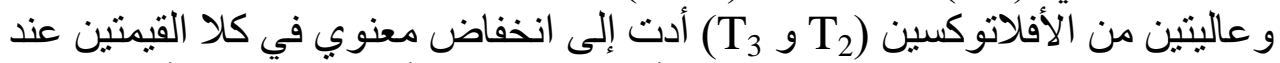

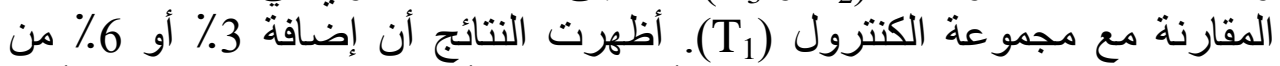

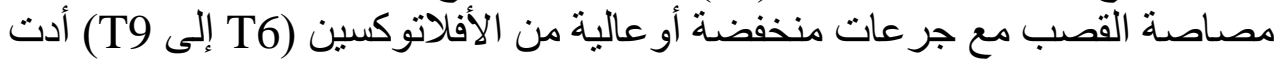

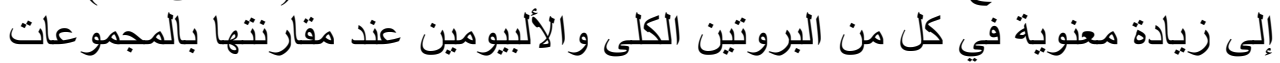

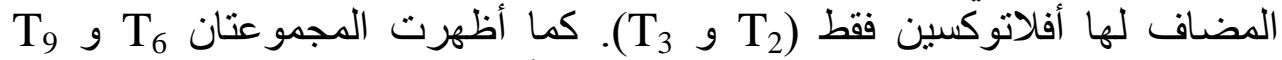

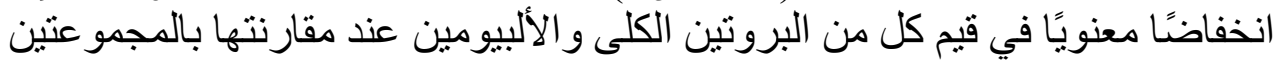

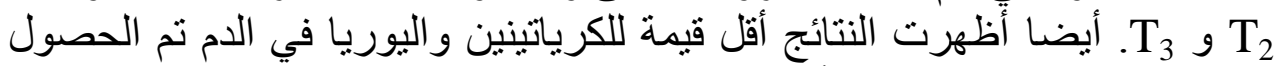

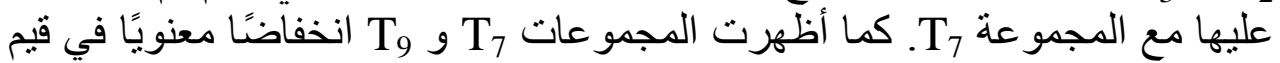

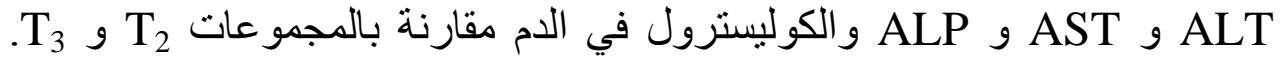

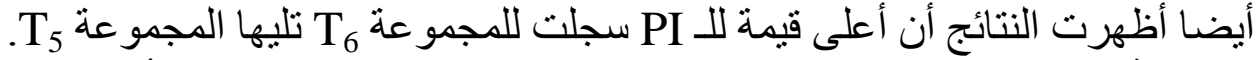

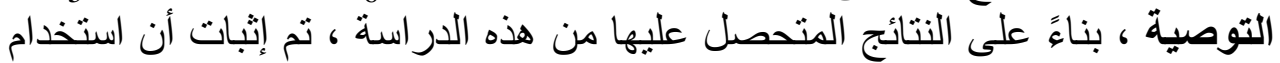

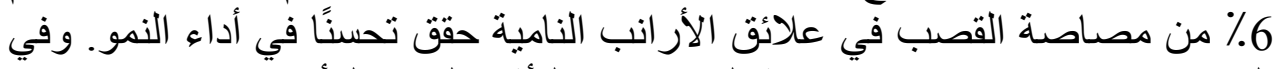

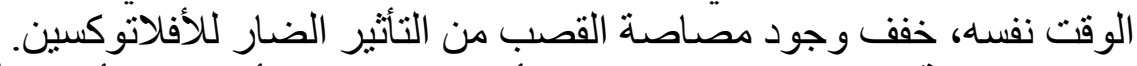

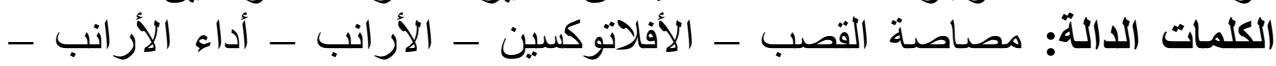
الكفاءة الإقتصادية. 